\title{
Realisasi Hak Anak dalam Film Capharnaum Karya Nadine Labaki
}

\author{
Alima Nuri Ayati ${ }^{*}$, Khomisah$^{2}$, Karman $^{3}$, Amiq $^{4}$. \\ 1*,2,3 UIN Sunan Gunung Djati Bandung, ${ }^{4}$ UIN Sunan Ampel Surabaya; ${ }^{*}$ alimanurhayati@gmail.com , \\ 2khomisah@uinsgd.ac.id , ${ }^{3}$ karman@uinsgd.ac.id, ${ }^{4}$ amiq@uinsgd.ac.id
}

*Penulis Korespondensi

Artikel Dikirim: 14 April 2021

Artikel Diterima: 19 Mei 2021

Artikel Dipublikasikan: 21 Juni 2021

\begin{abstract}
Abstrak: Film Capharnaum merupakan film yang berasal dari Lebanon yang disutradarai oleh seorang sutradara perempuan yang sekaligus menciptakan Naskah filmnya, bernama Nadine Labaki. Dia terinspirasi untuk membuat film tersebut dari pengalamannya yang melakukan riset dengan mengelilingi penjara anak yang ada di Suriah, mewawancarai anak-anak yang ada di dalam penjara tersebut dan mengambil suara-suara anak yang mengalami konflik dimasa kecilnya. Lalu sutradara mengambil kesimpulan dan ia tuangkan dalam naskah film. Mengambil narasi berlatar Beirut modern, yang sangat cocok untuk menggambarkan keadaan anak-anak yang mengalami kesengseraan dan kemiskinan yang luar biasa dikalangan anak-anak serta keterbaian oleh orangtuanya. Ditambah dengan para pemain actor yang diambil Nadine dari tempat pengungsian Suriah yang mengalami hal tersebut di kehidupan realitanya. Karena actor yang diambil bukan actor yang professional, menjadikan peran yang mereka mainkan menjadi penuh emosional sesuai yang mereka alami. Tema film ini menceritakan tentang kejahatan yang terjadi terhadap anak berbentuk eksploitasi anak, banyak ketidakadilan hak anak dalam film Capharnaum ini. Dengan demikian, untuk mencari makna teks yang mengandung bentuk eksploitasi anak tersebut perlu dicari menggunakan pendekatan kajian strukturalisme obyektif. Dalam intertekstual penelitian ini, meneliti dari segi struktur dan keterkaitan antar struktur tersebut, sehingga membentuk satu kesatuan makna yang utuh. Tujuan penelitian ini adalah untuk mengetahui teks-teks naskah film Capharnaum karya Nadine Labaki yang mengandung makna kata yang memiliki arti kedalam bentuk eksploitasi anak. Metode yang digunakan dalam penelitian ini yaitu metode deskriptif kualitatif.
\end{abstract}

Kata Kunci: Capharnaum. eksploitasi anak, realisasi hak anak, strukturalisme obyektif.

Abstract: The film Capharnaum is a film originating from Lebanon directed by a female director who also created the script for the film, named Nadine Labaki. He was inspired to make the film from his experience in conducting research by surrounding child prisons in Syria, interviewing children who were in the prison and taking the voices of children who experienced conflicts in their childhood. Then the director draws a conclusion and he puts it in a film script. Taking a narrative set in modern Beirut, which is very suitable to describe the situation of children who experience extreme misery and poverty among children and their parents neglect. Coupled with the actors who took Nadine from the Syrian refugee camp who experienced this in their real life. Because the actors who are taken are not professional actors, so the roles they play become emotional as they experience. The theme of this film tells about crimes that occur against children in the form of child exploitation, the many injustices of children's rights in this Capharnaum film. Thus, to find the meaning of a text that contains a form of child exploitation, it is necessary to look for an objective structuralism study approach. In this intertextual research, it examines the structure and linkages between these structures to form a unified whole meaning. The purpose of this study was to determine the texts of Nadine Labaki's Capharnaum film script which contain the meaning of words that have meaning in the form of child exploitation. The method used in this research is descriptive qualitative method.

Keywords: Capharnaum. child exploitation, realization of children's rights, objective structuralism. 


\section{Pendahuluan}

Pada zaman milenial sekarang sudah banyak fenomena yang terjadi dengan banyaknya anak remaja yang sudah menikah diusia muda. Tetapi tidak sedikit dari mereka yang belum memiiki kesiapan untuk menikah dari kesiapan fisik, mental maupun ilmunya. Karena sebuah proses pernikahan diperlukan kesiapan yang matang untuk menjalani rumah tangga. Salah satunya dari kesiapan ilmu, baik itu dari ilmu pernikahan, rumah tangga, parenting, keuangan, manajemen emosi, dan masih banyak lagi. Karena ilmu itu penting untuk bekal berumah tangga, agar mengetahui apa yang perlu dilakukan dalam kondisi dan situasi yang akan dihadapi nanti. Dari segi finansial juga perlu dipersiapkan. Karena dapat menjadi faktor masalah dalam berumah tangga. Kurangnya ilmu pun akan berpengaruh dalam membangun keluarga dan mendidik anak. Karena pendidikan seorang anak datang dari keluarganya.

Hal-hal yang akan terjadi akibat dari faktor ekonomi dan juga minimnya pengetahuan akan tanggung jawab orang tua dalam membesarkan anak adalah dampak besarnya terbebani terhadap anak. Seperti kurang terealisasinya hak-hak anak, dan terabaikan tanggungjawabnya sebagai orang tua. Salah satu contoh yang sering terjadi akibat dari faktor ekonomi yang belum tercukupi, dan dapat menimbulkan suatu konflik seperti terjadinya eksploitasi anak, dengan berbagai bentuk eksploitasi.

Anak sendiri disini diartikan sebagai seorang laki-laki atau perempuan yang belum dewasa atau belum mencapai umur 18 tahun dan belum menikah sebagaimana tercantum dalam Pasal 1 Konvesi PBB tentang hak anak 1989 (Delaney, 2006). jika untuk kata Eksploitasi dapat diartikan sebagai pemanfaatan untuk keuntungan sendiri atau pendayagunaan dengan tenaga orang. Awal munculnya eksploitasi adalah berasal masalah sosial yang melahirkan konflik sosial. Menurut Karl Max Ralf Dahrendorf bahwasannya masalah sosial muncul dimasyarakat diakibatkan dari tidak seimbangnya antara dua kekuatan, yaitu yang kuat dan lemah. Ditambah pihak yang kuat mengeksploitasi terhadap kelompok yang lemah. Ketidakberdayaan ini mengakibatkan kelompok lemah melakukan perlawanan sehingga memunculkan masalah sosial masyarakat (Jamaludin, 2016).

Berdasarkan fenomena ini, banyak sineas yang menggambarkan keadaan realitas kelas bawah dengan memunculkannya ke layar lebar menjadi sebuah film. Salah satu film yang mengangkat tentang eksploitasi anak tercermin dalam film "Capharnaum" produksi Lebnon karya Nadine Labaki yang sekaligus menyutradarai film tersebut. Film ini tercipta dari pengalaman Nadine yang melakukan riset dengan mengelilingi penjara anak dan pengungsian Suriah, mewawancarai anak-anak yang ada di dalam penjara tersebut dan mengambil jawaban suara anak yang mengalami kesengsaraan dan ketidakadilan dari konflik dan masalah hidupnya. Dari suara anak-anak Suriah Nadine membuat kesimpulan, jika mereka banyak yang kecewa oleh orang tuanya yang tidak berlaku adil terhadapnya, sehingga tidak memperoleh hak-haknya sebagai anak. Maka banyak dari mereka yang merasa "bahwa orang tuanya tidak pantas memilikinya". Dari hasil risetnya Nadine menjadi terbawa emosi dan terinspirasi untuk menuangkannya ke dalam Naskah film dan menciptakan karya film yang menggambarkan kisah para anak Suriah. Demi terciptanya adegan film yang nyata sesuai dengan kejadian aslinya, maka sutradara merekrut pemain atau aktor film dari para actor non-profesional yang amatir belum pernah memainkan film sebelumnya bahkan pemeran tokoh utamanya pun diambil Nadien dari pengungsi asli suriah yang pernah tinggal di Lebanon dan di audisi olehnya langsung dijalanan. Perekrutan aktor tak terlatih ini memberikan semacam autensitas, empati dan sensitivitas yang penting dalam film ini karena mereka 
membawa pengalaman hidupnya dalam memainkan perannya serta Nadien pun mengatur aktoraktornya untuk memainkan perannya dengan spontanitas mereka sendiri tetapi tepat tidak keluar dari skenario film (Haider, 2019). Sampai film ini mampu menghasilkan karya yang terbaik dan masuk dalam nominasi Oscars untuk kategori Best Foreign Language Film of the Year di Academy Awards 2019. Film ini pertama kali tayang di bioskop pada tanggal 14 Desember 2018.

Film ini lebih banyak mengisahkan tentang perspektif dari pemeran atau tokoh utamanya (Zain), yang memiliki konflik dari cerita film ini. mengisahkan tentang Zain yang terlahir dari keluarga miskin dan hidup di jalanan kota Beirut, yang menuntut orang tuanya sendiri di pengadilan, atas "kejahatan" karena telah melahirkannya ke dunia dengan penuh rasa sakit dan kesengsaraan. Akibatkan Perspektifnya berpusat pada: kehidupan kumuhnya terbatas di sekitar orangtuanya dan kakak adiknya yang banyak; insting alamiah anak-anaknya untuk bermain terjadi di antara jadwal kerjanya yang berat; dia lebih dibayang-bayangi oleh kehidupan penjara (seperti abangnya) daripada kemungkinan bersekolah; kekurangan makanan, kehangatan dan rasa sayang. Insting bertahan hidup Zain dan harga dirinya juga tercermin di Rahil (Yordanos Shiferaw), pekerja Ethiopia tanpa surat-surat resmi, yang berusaha merawat anaknya yang masih bayi, Yonas, dan menghindari deportasi. Sampai Zain yang nekat untuk melakukan tindakan criminal yang hendak membunuh (As'ad) yang menjadi suami karena dijual orang tuanya untuk dinikahkan dengannya dan sampai meninggal akibat hamil di usia yang sangat belia. Film ini merupakan bagian kuat dari tradisi sinema yang mewakili cara seorang anak melihat dunia dengan konflik-konfliknya.

Perkawinan anak dan memperkerjakan anak usia sekolah secara paksa, selain melanggar hak-hak anak dengan memaksa mereka berhenti sekolah, juga mengakibatkan kemiskinan antar generasi, merusak pendidikan jangka panjang mereka, kemampuan untuk mencari nafkah. Dan fenomenafenomena yang terjadi dalam film ini dapat dilihat dari unsur sinematik dan narasi yang terkandung dalam film.

Film adalah rangkaian adegan yang didalamnya terdapat pemerannya sehingga menyajikan cerita yang dimaksud. film memuat cerita-cerita (fiksi dan non fiksi) seperti halnya sastra. film itu memiliki kokretisasi pengalaman, harapan, dan imajinasi manusia dalam bentuk media visual. Aspek cerita dan tema sebuah film terdapat di dalam narasi. Cerita dikemas dalam bentuk skenario, sehingga dapat melihat unsur-unsur seperti tokoh, masalah, konflik, latar tempat/lokasi dan latar waktu, dan lain sabagainya.

Dari Seluruh unsur tersebut dapat ditemukan dengan meneliti secara mendalam menggunakan kajian Strukturalisme Obyektif. Dalam strukturalisme Objektif mengkaji unsur intristik suatu karya sastra. Serta mengkaji keterkaitan antar unsur satu dengan lainnya, sehingga membentuk suatu makna yang utuh. Makna tersebut terkandung dalam narasi atau naskah film yang menunjukkan kepada bentuk-bentuk eksploitasi dalam film Capharnaum.

Pada penelitian ini peneliti menggunakan metode penelitian deskriptif kualitatif yaitu penggambaran secara kualitatif fakta, data, atau objek material yang bukan berupa rangkaian angka melainkan berupa ungkapan bahasa atau wacana melalui interpretasi yang tepat dan sistematis (Wibowo, 2011). Kemudian menggunakan studi pustaka atau Library research sebagai teknik pengumpulan data. 


\section{Pembahasan}

\subsection{Strukturalisme Obyektif}

Strukturalisme merupakan suatu cara pandang yang menekankan persepsi dan deskripsi tentang unsur struktur seperti diuraikan oleh Pieget tersebut (Kridalaksana, 2005). Adapun prinsip dasar dari strukturalisme yaitu alam semesta terjadi dari relasi (Saussure: forma) dan bukan benda (Saussure: subtansi). Strukturalisme berkembang sejak tahun 1930-an dan dipraksai oleh strukturalis Ceko. Adapun tokoh utama aliran strukturalisme Ceko adalah Roman Jakobshon yang berasal dari kaum Formalis, Jan Mukarovsky, serta Felix Vodicka yang memiliki minat atas sejarah perkembangan sastra. Dalam perkembangannya analisis structural mengalami perubahan dari strukturalisme murni (statis, strelir, mandul) ke strukturalisme dinamik (subur, fertile, menstruktur). Strukturalisme murni adalah suatu analisis structural yang hanya memandang kepada keterkaitan unsur-unsur yang ada dalam struktur karya sastra yang bersangkutan. Sedangkan strukturalisme dinamik adalah analisis structural yang tidak hanya memperhatikan sejumlah unsur yang ada dalam struktur karya sastra yang bersangkutan, tetapi sudah keluar dari strukturnya yang dipandang sebagai sistem "tanda” (sign) (Sangidu, 2018).

Suatu unsur mempunyai tiga ciri: Pertama, memiliki makna yang beragam. Setiap unsur dalam makna memiliki makna yang berbeda atau bermacam-macam, karena berasal dari yang juga memiliki beragam latar belakang pengetahuan. Serta hubungan antar unsur yang dibangun perlu diamati secara seksama agar menghasilkan struktur baru dalam pemahaman teks yang maknanya beragam. Kedua, pemahamannya tergantung pada konteks kata. Maka diperlukannya ilmu linguistik dalam pemahaman kata dalam sebuah struktur, yang menjadikan struktur memiliki dua konteks makna, yaitu struktur sebagai suatu pemikiran (konsep) dan struktur sebagai aplikasi dari konsep. Ketiga, sifatnya fleksibel dan lentur. Struktur terdiri dari banyak makna yang bergantung pada konteksnya, sebuah konteks berfungsi sebagai Batasan makna yang menjadikan konsep struktur tersebut fleksibel dan lentur. Dan membuat pemahaman terhadap Sebagian besar bentuknya dan hubungan antar bentuknya bersifat relatif (Yonata \& Mujiyanto, 2017).

Terdapat beberapa gagasan pokok terpenting dari strukturalisme Saussurean yang dapat diuraikan sebagai berikut:

1. Strukturalisme pada hakikatnya mengartikan dunia yang dihadapi manusia itu dipenuhi oleh makna-makna yang tersimpan, karena tidak akan ada dunia tanpa makna. Dan makna tersebut ada bagi manusia sebagai suatu struktur-struktur yang tertata dan menjadi orientasi gerak manusia.

2. Strukturalisme didalamnya terdapat asumsi aktivitas sosial dapat dipahami sebagaimana kita memahami Bahasa itu sendiri. Dapat diartikan pula bila Bahasa adalah model untuk memahami struktur dunia sosial-budaya manusia.

3. Jika dilihat dari sudut linguistik Saussure 'langue' dan 'parole'. Para strukturalis memahami akan adanya sebuah struktur dalam (deep struktur) yang sejajar dengan langue, dan struktur permukaan (surface structure) yang sejajar dengan parole dalam setiap aktivitas sosial-budaya manusia dan hasil-hasilnya. 
4. Unsur-unsur dalam satu fenomena sosial budaya lebih dapat dijelaskan maknanya dengan melihat relasi-relasinya pada penggalan waktu tertentu (sinkronis) daripada melihat relasi-relasi dan perkembangannya dalam rentangan waktu diakronis).

5. Relasi-relasi antar unsur yang berada dalam sebuah struktur merupakan penghadir dan penentu makna.

Strukturalisme Objektif merupakan sebuah struktur yang unsur-unsurnya saling berkaitan, sehingga unsur-unsurnya tidak memiliki makna dengan sendirinya akan tetapi, maknanya ditentukan oleh keterkaitan unsur-unsur tersebut sampai terbentuk totalitas makna. Strukturalisme juga mendekati dunia teks yang mana mempertimbangkan aspek semantik dari setiap fitur tekstualnya (Scholes, 1977).

\subsubsection{Sinopsis Film Capharnaum}

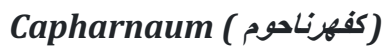

Sutradara

Produser

Pemeran

Musik

Sinematografi

Penyunting

Perusahaan Produksi

Distibutor

Tanggal rilis

Durasi

Negara

Bahasa
: Nadine Labaki

: Michel Merkt

Khaled Mouzanar

: Nadine Labaki

Jihad Hojaily

Michelle Keserwany

Georges Khabbaz

Khaled Mouzanar

: Zain Al Rafeea

Yordanos shiferaw

Boluwatife Treasure

Bankole

: Khaled Mouzanar

: Christopher Aoun

: Konstantin Bock

: Mooz Films

: Sony Picture Classics

: 17 Mei 2018 (Cannes)

20 September 2018 (Lebanon)

: 123 menit

: Lebanon

: Arab Lebanon

(https://id.wikipedia.org/wiki/Capernaum\#Pemeran),

Film Capernaum yang mengisahkan lebih banyak kepada prespektif tokoh utamanya Zain Al Rafeea (pengungsi Suriah yang di deportasi ke Kenya) anak 12 Tahun yang menuntut orang tuanya, atas 
ketidakadilan hidup yang dirasakan, telah membesarkannya dalam kemiskinan dan kesengsaraan yang membebankan itu semua kepada anak-anaknya dengan memperkerjakan mereka, tidak mendapatkan haknya untuk bersekolah, lalu ia kabur dari rumahnya saat kedua orangtuanya hendak menjual adik perempuannya yang masih berusia 11 Tahun. Ia ditampung oleh pekerja asing Eithopia, Zain menjaga anaknya sebagai imbalan. Tak lama dari itu dia mendengar kabar adik perempuannya meninggal. Timbul tindak kriminal darinya karena emosi yang sudah tidak tertampung dengan menikam laki-laki yang telah membeli adiknya atau suami adiknya, dan akhirnya ia dipenjara. Saat Zain berada dalam penjara ia menyuarakan pengalaman hidupnya melalui telepon yang menyambungkannya ke siaran acara televisi.

\subsection{Wujud Unsur Intristik Film Capharnaum}

\subsubsection{Tema}

Tema merupakan gagasan awal dan merupakan makna isi sastra secara keseluruhan, menjadi pondasi dan memiliki fungsi sebagai penyeimbang keseluruhan sistem. Didalam film Capharnaum terdapat tema tentang Kejahatan yang dilihat dari peristiwa-peristiwa yang terjadi di film Capharnaum terdapat kekerasan pada anak, eksploitasi anak dan ketidakadilan pada anak.

\subsubsection{Alur atau plot}

Dalam penyajian cerita film, yang dirangkai dari peristiwa-peristiwa yang dialami oleh tokoh akan menggambarkan sebuah alur. Rangkaian peristiwa di dalam film dirangkai menjadi rangkaian bulat yang mempunyai sebab akibat. Dan Film Capharnaum menggunakan plot campuran atau maju-mundur karena tidak secara mutlak berplot luruskronologis atau sebaliknya sorot-balik. Karena tidak ada juga cerita yang mutlak flashback. Jika dituliskan dalam bentuk skema, secara garis besar plot campuran tersebut akan berwujud sebagai berikut.

$\mathrm{E} \longrightarrow \mathrm{D} 1 \longrightarrow \mathrm{A} \longrightarrow \mathrm{B}-\mathrm{C} \longrightarrow \mathrm{D} 2$

Tabel 1. Jenis Alur

\begin{tabular}{c|cc}
\hline No. & Visual & Jenis Alur \\
\hline 1. & Tahap awal \\
Exposition
\end{tabular}




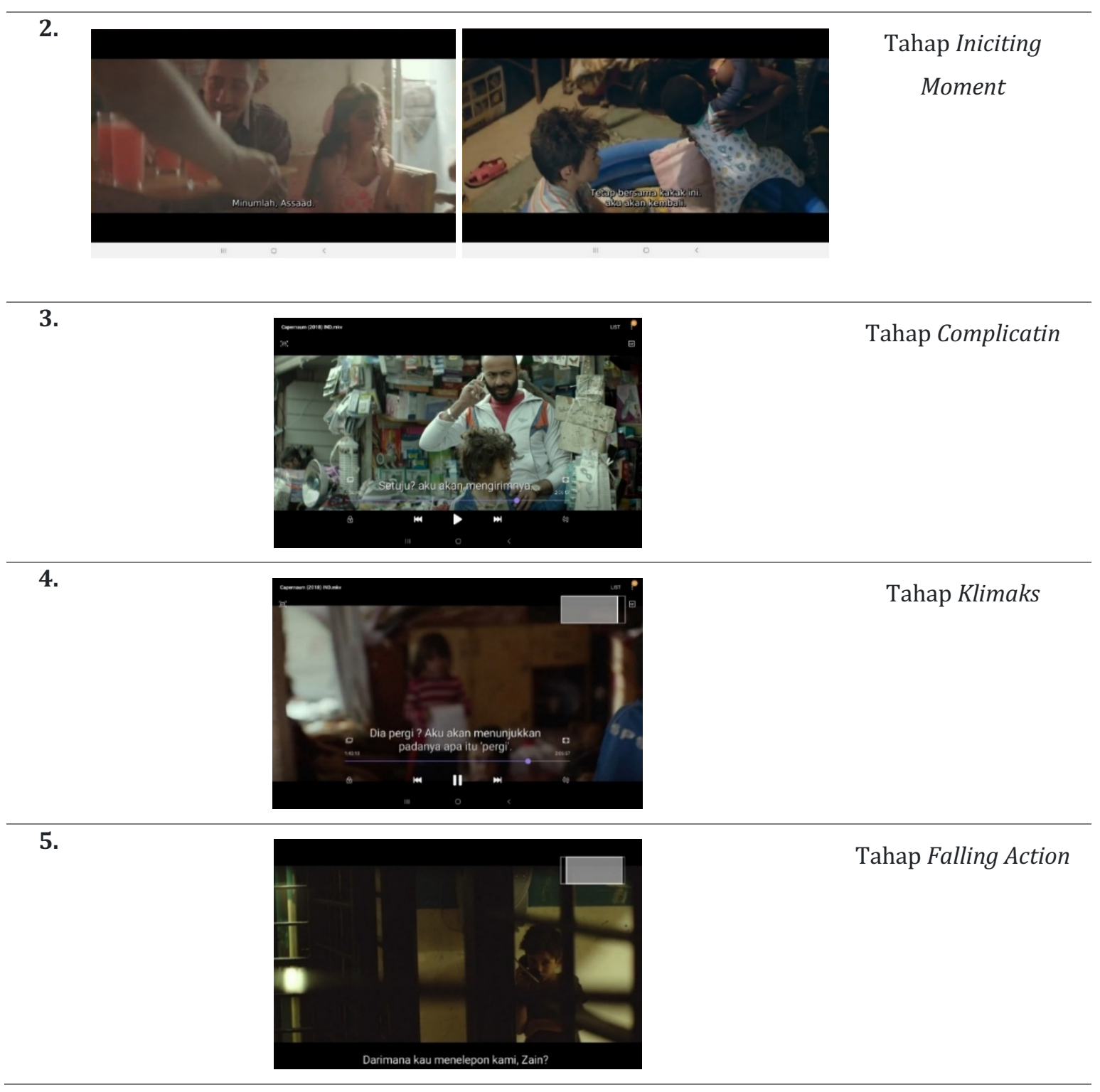

Adegan A, B, C merupakan biografi seorang tokoh, yang berisi inti cerita film. Diceritakan secara runtut-progesif-kronologis. Kisah tersebut mengantarai adegan D1 dan D2 yang juga lurus-kronologis. Adegan E merupakan kelanjutan langsung dari peristiwa D2 justru ditempatkan di awal cerita, namun bagian E bersifat lurus-kronologis., seperti yang dapat dilihat dari alur rangkaian berikut:

1. Tahap awal Exposition

Eksposisi merupakan tahap awal cerita dimana pengarang mulai memperkenalkan tempat, kejadian, waktu, topik, dan tokoh. Dalam film ini diawali dengan menampilkan tokoh utama, orang tua tokoh utama dan sutradara yang ikut peran dalam film sebagai pengacara Zain yaitu Zain (tokoh utama), Souad dan Selim (orang tua), Nadine Al-Aalam (pengacara).

\section{Tahap Inciting Moment}

Inciting moment adalah pemunculan masalah atau konflik yang ditampilkan oleh sutradara film yang terdapat dalam alur cerita film Capharnaum. Pemunculan konflik ini 
dimaksudkan agar dapat dikembangkan membentuk dramatic dalam penyampaian alur cerita terhadap penonton ini. Konflik didalam film Capharnaum mulai Nampak saat Selim dan Souad berencana memberikan anak perempuan keduanya Sahar yang masih dibawah umur kepada keluarga Assad yang telah membantu banyak kepada keluarganya untuk dinikahkan kepada anak laki-lakinya Assad yang telah menyukai Sahar.

Rising Action merupakan penanjakan dari masalah atau konflik pada alur cerita film Capharnaum yang terus mengalami pernanjakan. Dalam tahap ini konflik didalam film Capharnaum mengalami penanjakan saat Zain yang langsung melarikan diri dari rumahnya karena merasa kesal dan kecewa terhadap orang tuanya, dan saat dia mencari pekerjaan dia bertemu dengan Imigran illegal Eithopia bernama Rahil bersama dengan bayinya Yonas, dan dibawa kerumahnya diajak untuk tinggal bersamanya karena merasa kasihan melihatnya terlantar.

\section{Tahap Complication}

Complication (perumitan) adalah konflik yang semakin rumit atau sulit, peristiwa dramatik yang menjadikan cerita semakin menegangkan. Dalam film ini mulai terlihat menegangkan pada konflik saat Zain dihadapkan masalah pada dirinya diluar naungan orang tuanya, harus dihadapi dirinya sendiri diumurnya yang masih muda harus menanggung beban hidup merawat bayi yang ditinggal ibunya saat ibunya tertangkap oleh polisi karena tidak berhasil memiliki identitas palsunya.

\section{Tahap Klimaks}

Klimaks adalah dimana suasana alur peristiwa konflik mencapai puncaknya masalahnya yang menjadi inti cerita. Tahap ini muncul pada film Capharnaum saat, Zain bergegas pergi kerumah untuk mengambil berkas-berkas itu, tapi saat dia bertemu orang tuanya hanya amarah dan kekerasan yang didapatnya karena sudah lama tidak pulang ke rumah. Tetapi saat mendengar bahwa ada surat dari rumah sakit, dari itu Zain mulai curiga dengan siapa yang berada di ruamh sakit, maka dia menanyakan hal itu kepada orang tuanya walau pada awalnya tidak ada yang mau menjawabnya tapi pada akhirnya mereka memberitahu bahwa adiknya Sahar yang berada di rumah sakit karena tidak terselamatkan dari kehamilan mudanya dan berakhir dengan maut. Saat Zain mendengar kabar tersebut, amarahnya yang tak terbendung lagi memberenikan dirinya untuk membalas dendam kepada Assad dengan membawa pisau hendak mau membunuhnya untuk menunjukannya arti 'pergi' sebenarnya.

\section{Tahap Falling Action}

Peleraian (falling action) bagian ini menampilkan tahap tertentu sebagai akibat dari klimaks. Pada bagian ini berisi bagaimana akhir sebuah cerita film. Pada peleraian konflik didalam film Capharnaum, yaitu diadakannya kembali sidang kedua yang mana orang tuanya dipanggil kembali untuk menghadiri persidangan tetapi tidak untuk sebagai saksi, disana orang tuanya membela anaknya, tetapi hakim mempersilahkan Zain berbicara, lalu yang Zain inginkan dari orang tuanya adalah bahwa ia tidak ingin orang tuanya memiliki anak lagi. Dan untuk masalah Aspro yang mengeksploitasi anak Rahil, telah berhasil ditangkap dan Yonas pun telah ditemukan ditempat persembunyian Aspro, dan dikembalikan ke Rahil. Zain juga tak lama dari itu dibebaskan dari penjara. 


\subsubsection{Tokoh dan penokohan}

Keadaan tokoh bisa menjadikan cerita itu seperti kejadian nyata. Watak tokoh bisa menjadi konflik yang membentuk cerita. Pada film Capharnaum karya Nadine Labaki, terbentuk dari satu tokoh utama dan tokoh tambahannya ada enam.

Tabel 2. Tokoh Utama

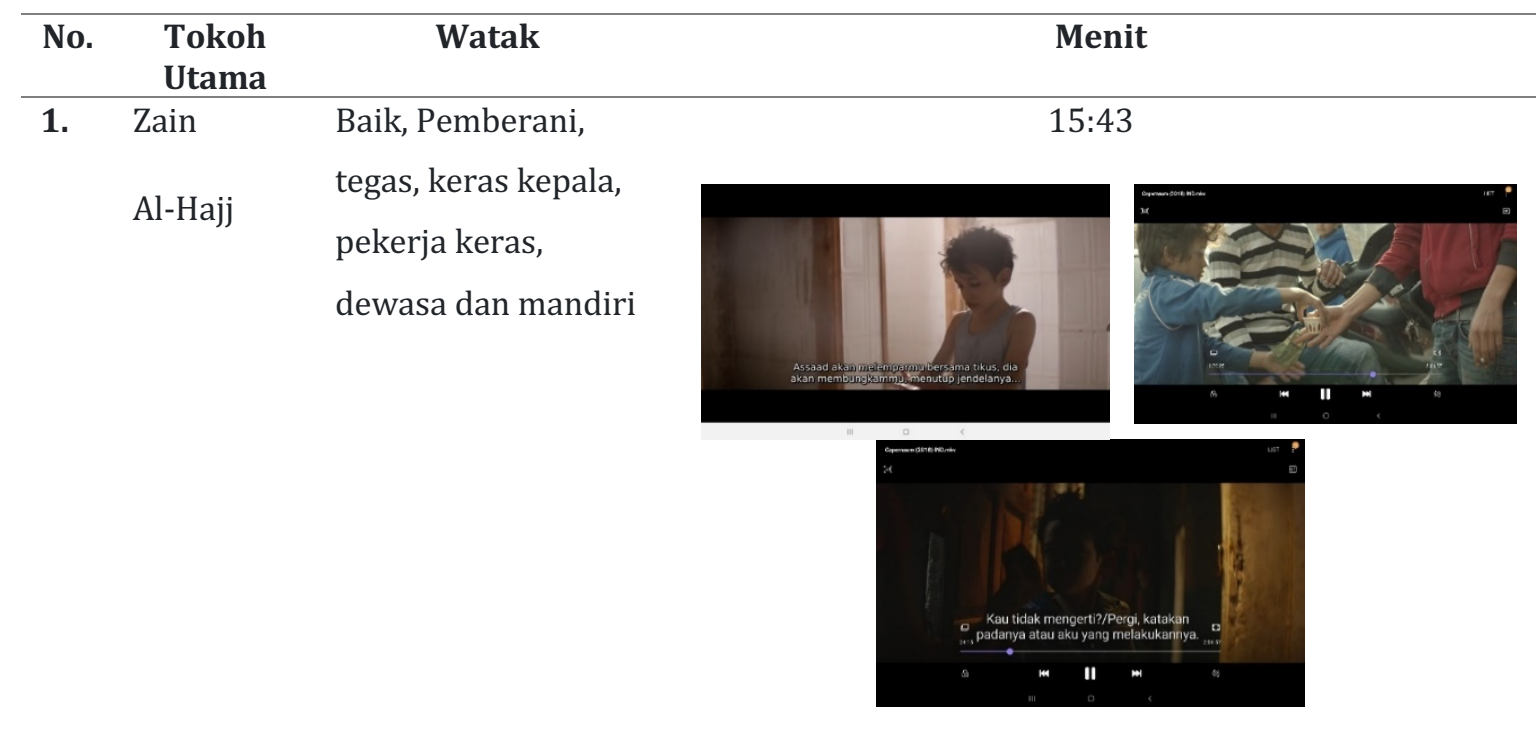

2. Sahar Baik, penurut dan

$16: 13$

penyayang

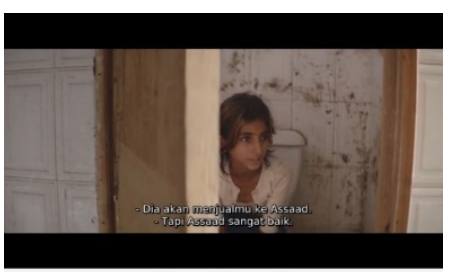

3. Souad Keras, pemarah dan

$30: 23$

penyayang

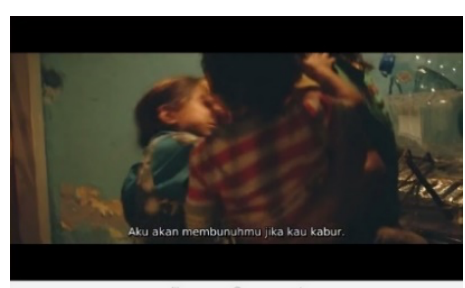

4. Selim Keras, pemarah dan 21:14

penakut
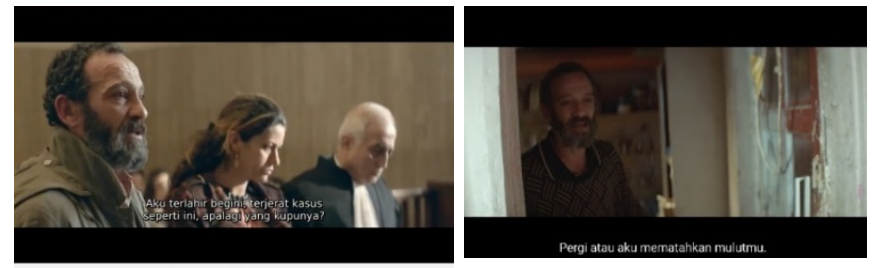


\begin{tabular}{l} 
5. Rahil $\begin{array}{l}\text { Baik hati, } \\
\text { penyayang, rela } \\
\text { berkorban, dan } \\
\text { pekerja keras }\end{array}$ \\
\hline Aspro \\
Jahat, pembohong
\end{tabular}

Tabel 3. Tokoh Tambahan 1

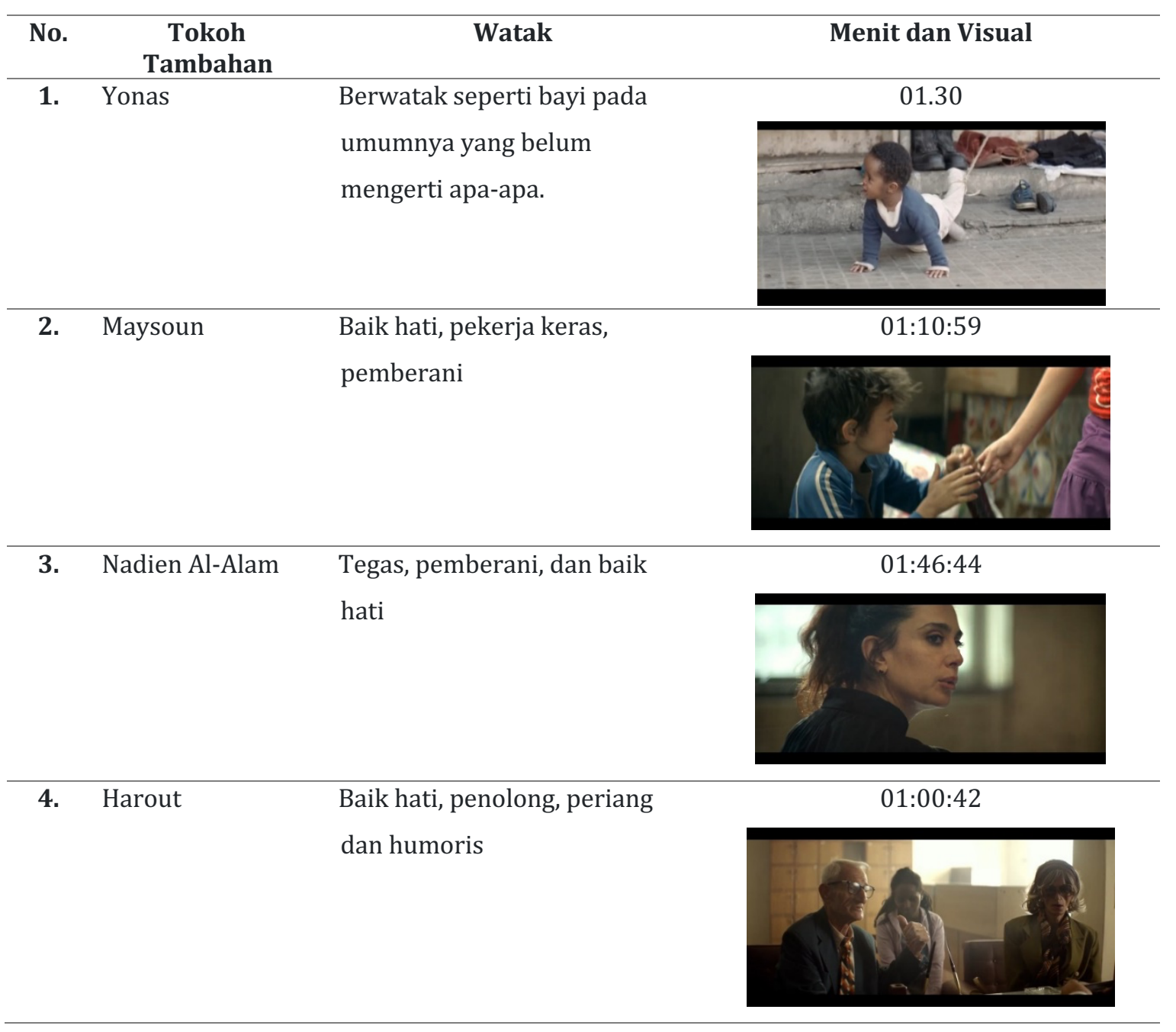




\subsubsection{Latar / setting waktu dan tempat}

Yang dimaksud Latar dalam penelitian ini adalah tempat kejadian. Latar adalah gambaran mengenai tempat, ruang dan waktu atau segala situasi terjadinya peristiwa. Latar atau setting yang ditemukan pada fil Capharnaum di deskripsikan berikut.

Tabel 4. Latar Tempat 1

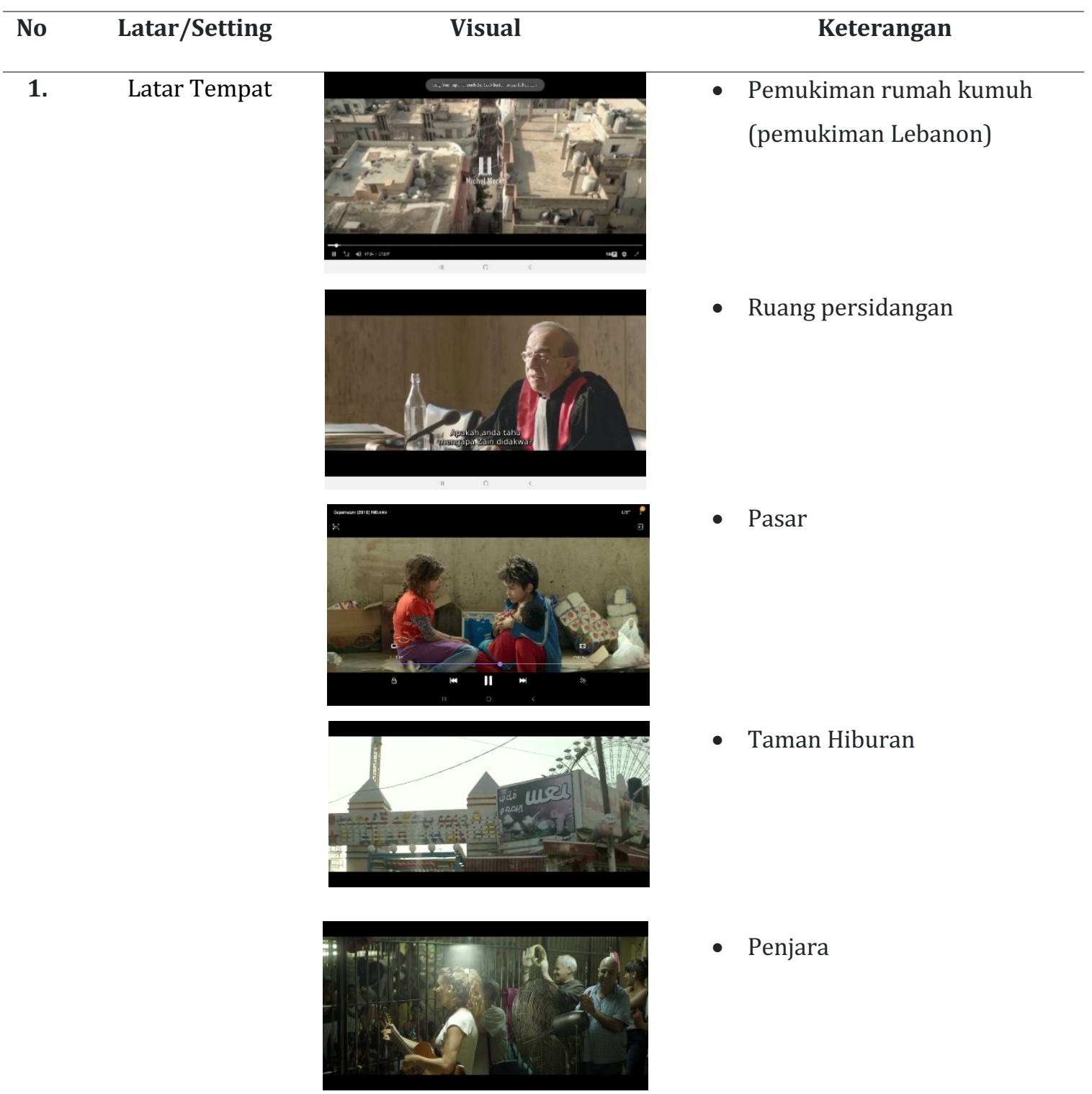

Selanjutnya latar waktu yang ditemukan pada hasil analisis film Capharnaum, terdapat waktu siang dan malam. Jika pada waktu siang adalah saat yang banyak digunakan dalam film ini yaitu saat persidangan Zain dan Rahil dilangsungkan, saat Souad dan Zain juga adiknya menjenguk sepupunya di penjara, saat Zain dan adik-adiknya berkerja menjual jus juga Zain yang mengantar belanjaan ke tempat pesanan, saat perundingan keluarga Assad dan Souad serta Salim yang hendak menjual Sahar, saat Zain berencana membawa Sahar kabur, saat Zain kabur dari rumah dan pergi ke taman hiburan mencari pekerjaan, saat Rahil berkerja dan mencari bantuan untuk memalsukan identitasnya, saat Zain bertahan hidup 
dengan Yonas saat sedang ditinggal Rahil, saat Zain bertemu Maysoun, saat Zain bertemu Aspro dan akhirnya menyerahkannya dan saat Souad menjenguk Zain di penjara. Jika saat malam hari saat keluarga Zain berkumpul untuk makan malam bersama dan membicarakan perihal sekolah Zain dan Sahar, saat Zain bertemu Rahil untuk kedua kalinya dan dibawa kerumahnya, saat Rahil merayakan ulang tahun Yonas anaknya dan membawakannya kue ulang tahun bekas dari tempat kerjanya, saat Rahil bertemu pacarnya yang membantunya memberikan kartu identitas bosnya untuknya, saat Zain dan Yonas mencari makan ke pasar saat ditinggalkan Rahil, saat Rahil tertangkap polisi karena statusnya sebagai imigran illegal yang belum mempunyai identitas resmi, saat Zain menjual minuman Tramadol buatannya kepada para pemabuk dengan ditemani Yonas, saat Zain menelpon siaran TV yang menampung kisah ketidakadilan terhadap anak, dan juga saat Aspro tertangkap oleh polisi di markasnya serta ditemukannya Yonas disana.

\subsubsection{Amanat}

Amanat merupakan pesan yang ingin disampaikan oleh pengarang terhadap apresiatornya. Menurut hasil analisis penulis amanat utama yang dapat dipetik dari film Capharnaum yaitu terkandung dalam kalimat pesan Zain yang disampaikannya ke siaran televisi melalui telepon pejara:

"Aku mengeluh kepada orang tuaku, pesan ini untuk orang dewasa yang tidak mampu membesarkan anak-anaknya. Apa yang akan aku ingat? Dari kekerasan, penghinaan, atau pemukulan, rantai, pipa atau sabuk. Kata termanis yang mereka berikan padaku adalah 'bangsat, bajingan, sampah!' hidup adalah masalah besar, tidak lebih berharga dari sepatuku, aku tinggal di neraka ini, aku terbakar seperti daging dikremasi, hidup seperti seekor anjing. Aku pikir kita akan menjadi orang baik, dan dihargai oleh semua orang. Tapi Rabb tidak ingin itu terjadi kepada tidak ingin itu terjadi pada kami. Dia lebih suka menyimpan kebahagiaan untuk orang lain".

Maksud dari kutipan pesan tersebut adalah setiap orang dewasa perlu menyiapkan dengan matang sebelum memiliki anak, perlu tahu bagaimana cara merawat anak dan memperlakukan anak dengan baik, hak-hak anak perlu terpenuhi dengan baik. Jangan melepas tanggung jawab sebagai orang tua dalam menjaga anaknya hanya karna masalah ekonomi, sehingga rela mengorbankan anak demi memperbaiki kondisi perekonomian keluarga.

\subsubsection{Sudut Pandang}

Sudut pandang merupakan cara cerita yang diceritakan oleh pengarang. Dan merupakan salah satu cara atau pandangan yang digunakan oleh pengarang untuk menjelaskan tokoh, Tindakan, latar dan berbagai peristiwa didalam cerita. Menurut analisis penulis naskah, sudut pandang yang digunakan didalam film Capharnaum karya Nadine Labaki, menggunakan sudut pandang persona orang ketiga yaitu sudut pandang yang menjelaskan cerita dari sudut pandang (Dia) "Zain" tetapi pengarang, narrator bisa menceritakan apa saja yang berhubungan dengan tokoh "dia" tersebut. Narrator harus mengetahui berbagai hal tentang tokoh, peristiwa, dan Tindakan termaksud motivasi yang menjadi penyebabnya. 


\subsection{Keterkaitan antar Unsur-Unsur Instristik dalam film "Capharnaum" karya Nadine Labaki}

Keterkaitan antar unsur. Keterkaitan antara unsur dalam film yaitu keterkaitan antara alur/plot, tokoh, latar/setting, amanat, serta sudut pandang yang terikat dengan tema menjadi dasar dalam pembuatan karya sastra.

1. Tema berkaitan erat dengan Alur/Plot.

Tema didalam film "Capharnaum" ini ada kaitannya dengan semua isi cerita pada film tersebut. Alur/Plot menjelaskan tema dengan semua unsur yang lain, begitu juga tema ini menggambarkan apa yang terjadi didalam alur ini. Dengan itu tema dan alur/plot sangat erat kaitannya karena tanpa adanya tema dan alur/plot cerita didalam film Capharnaum tidak bisa diketahui seperti apa tema didalam film dan bagaimana alur/plot yang terdapat didalam film.

2. Tema berkaitan erat dengan tokoh

Tema dan alur yang diceritakan didalam film Capharnaum kaya Nadine Labaki ini tidak bisa dceritakan tanpa keberadaan tokoh Zain, ibu (Souad), ayah (Selim), Rahil, Yonas, Aspro, Maysoun dan lan-lain. Semua kejadian yang dilakukan oleh semua tokoh pada akhir cerita itu, maka semua cerita didalam film itu menunjukkan bahwa ada kaitannya antara tema, alur/plot dengan tokoh.

3. Tema berkaitan erat dengan Latar.

Pada film Capharnaum ini bisa dilihat pada peristiwa yang menjelaskan tetang latar dimana tempat kejadian dan kapan waktunya. Latar tempat yang digunakan seperti pada tokoh dari (pemukiman rumah Lebanon, ruang pengadilan, toko, taman hiburan, rumah kumuh, dan pasar). Latar waktu yang digunakan seperti pada peristiwa yang terjadi menurut alurnya. Latar ini dilakukan dengan cara, bagaimana tokoh mengalihkan salah satu peristiwa sehingga bisa memilih tema. Sebaliknya tema yang sudah dipilih juga menentukan latar yang tentunya harus sama dengan tema.

4. Tema berkaitan erat dengan amanat

Tema dan amanat adalah salah satu dari sejumlah pembangun cerita yang lain, yang secara bersama membentuk sebuah keseluruhan yang utuh. Tema sangat berkaitan erat dengan amanat karena didalam cerita (film) terdapat makna yang berkaitan dengan amanat, makna yang terkandung dalam sebuah cerita dapat menghidupkan sebuah cerita.

5. Tema berkaitan erat dengan Sudut Pandang

Tema tidak dapat dipisahkan dengan sudut pandang begitu juga dengan alur/plot, tokoh, latar dan amanat. Sudut pandang menggunakan orang ketiga "Dia" (Zain) yang digunakan pengarang didalam film Capharnaum ini memudahkan pengarang dalam menggambarkan apa yang dibicarakan tokoh serta semua kejadian yang dialami oleh tokoh. 


\section{Alur/ berkaitan dengan tokoh}

Plot berkaitan erat dengan tokoh karena menjadi jalan penentu tokoh memainkan perannya, dan pemahaman cerita sangat ditentukan oleh plot. Dalam hal ini alur berkaitan erat dengan tokoh karena dalam hal ini yang berperan adalah Zain sebagai seorang anak yang tidak mendapat keadilan hak anak dari orang tuanya.

\section{Alur/Plot berkaitan erat dengan latar}

Selain itu alur/plot juga punya kaitannya dengan latar, karena alur/plot cerita dalam film dapat terlihat hidup dicipatakan dari adanya latar, begitu juga tokoh. Misalnya latar tempat, latar waktu, latar sosial yang saling berkaitan satu sama lain membentuk karya sastra. Misalnya yang terdapat dalam film Capharnaum yaitu latar tempat ada di ruang persidangan, latar waktu yang digunakan adalah siang hari, sedangkan latar sosialnya adalah tingkatan sosial bawah, dan untuk suasana tempat yang penuh ketenggangan dengan konflik.

\section{Alur/plot berkaitan erat dengan amanat}

Alur sangat berkaitan erat amanat karena didalam alur cerita terkandung makna yang berkaitan dengan amanat, makna yang terkandung itu dapat menghidupkan sebuah cerita. Masalah yang diangkat didalam film Capharnaum yaitu yang menghidupkan cerita menjadi sebuah amanat.

\section{Alur/plot berkaitan erat dengan sudut pandang}

Sudut pandang ini memiliki peranan penting dalam membentuk semua unsur tersebut karena sudut pandang sarana untuk menyampaikan makna dalam cerita yang disampaikan dengan pembaca. Sudut pandang peristiwa persona ketiga "Dia" (Zain) yang digunakan pengarang didalam film Capharnaum ini memudahkan pengarang dalam menggambarkan apa yang dibicarakan tokoh serta semua kejadian yang dialami oleh tokoh. Karena itu pembaca bisa lebih mudah mengetahui masingmasing tokoh dan cerita menjadi hidup.

\section{Tokoh berkaitan erat dengan latar}

Penokohan dan latar mempunyai keterkaitan yang erat yang bersifat timbal balik. Sifat latar yang mempengaruhi sifat tokoh. Bahwa sifat seseorang akan dibentuk oleh keadaan latar. Pengangkatan tokoh tergantung juga dari tingkat sosial dia berada, jika dari kelas sosial rendah tentu akan berbeda dengan tingkat sosial tinggi, misalnya dalam cara bertingkah laku, bepikir, dan bersikap.

\section{Tokoh berkaitan erat dengan amanat}

Tokoh sangat berkaitan erat dengan amanat yang terkandung dalam sebuah cerita dapat menghidupkan sebuah cerita. Amanat yang diangkat di dalam film Capharnaum yaitu amanat tentang pesan terhadap orang dewasa agar dapat bertanggungjawab atas setiop anak yang terlahir ke duniadan bersikap adil terhadap anaknya, jangan hanya ingin memiliki tetapi tidak mau merawat.

12. Tokoh berkaitan erat dengan sudut pandang

Tokoh yang menjalankan isi cerita didalam film, dan menerangkan apa yang diinginkan oleh pengarang, dan pengarang mengisahkan cerita itu melalui tokoh. Dan tokoh tidak bisa dipisahkan 
dengan sudut pandang karena di dalam sudut pandang ini pengarang sebagai narrator yang menceritakan sebuah cerita itu melalui tokoh.

13. Latar berkaitan erat dengan amanat

Latar dan amanat tersebut menjadi jalan cerita jika ada keterkaitannya dengan unsur-unsur cerita yang lain. Latar sangat berkaitan erat dengan amanat karena didalam cerita (film) terdapat latar tempat, latar waktu latar sosial yang berkaitan dengan amanat, yang menentukan sebuah amanat atau pesan yang terkandung dalam sebuah cerita.

14. Latar berkaitan erat dengan sudut pandang

Pada hal ini latar berkaitan dengan sudut pandang, karena cerita didalam film tidak akan pernah hidup tanpa adanya sudut pandang yang menjelaskan tentang pengarang sebagai narrator. Sehingga sangat berkaitan karena tanpa adanya latar tidak akan mengetahui sudut pandang yang berkaitan.

15. Amanat berkaitan erat dengan sudut pandang

Amanat berkaitan erat dengan sudut pandang karena amanat merupakan ajaran moral atau pesan yang akan disampaikan pengarang pada penonton. Sehingga pengarang sebgaai narrator dalam menyampaikan pesan pengarang pada penonton yang disampaikan melalui karyanya.

\subsection{Keterangan dari setiap bentuk Eksploitasi anak yang terdapat dalam film Capharnaum:}

1. Eksploitasi Fisik

Pada naskah pertama menunjukan dialog dimana anak-anak yang masih dibawah umur sedang berjualan jus buah dijalanan, dan itu atas perintah orang tuanya. Tindakan ini sudah termasuk kedalam penyimpangan hak anak atau bentuk eksploitasi anak berjenis eksploitasi fisik karena telah memanfaatkan dalam penyalahgunaan tenaga anak untuk diperkerjakan demi keuntungan orang tuanya yang tidak bertanggung jawab dengan membebankan dengan menyuruh anak berkerja. Yang seharusnya anak yang masih dibawah umur itu, masih dibawah nangungan asuhan orang tuanya dan mendapat nafkah dari orang tuanya tetapi justru tidak mendapatkannya dan sudah dibebani membantu memenuhi kebutuhan ekonomi atau hidup keluarga. Dan ini cukup menganggu fisik dan psikis anak pada tumbuh kembangnya.

\section{Eksploitasi sosial}

Pada naskah berikut menunjukkan dialog antara ayah, ibu dan anak yang sedang berkumpul makan malam yang berbincang mengenai Pendidikan anaknya atau sekolah, disini ayahnya kurang setuju dengan permintaan anaknya yang ingin bersekolah tetapi dilain sisi ibunya setuju dan masih mendukung kemauan anaknya tetapi masih dengan melihat keuntungan dari sekolah yang bisa meringankan beban keluarganya seperti dengan anaknya dapat makan disekolah dan membawa makanan untuk adik-adiknya, juga mendapat baju, itu sudah diluar tujuan dari sekolah untuk mendapat Pendidikan. Dan ini sudah menghambat anak-anak dalam mendapatkan haknya yaitu Pendidikan. Dan termaksud kedalam bentuk ekploitasi anak karena orang tuanya melakukan penolakan terhadap anak atas permintaanya untuk bersekolah, yang mana ayahnya masih ada rasa takut dan cemas jika As'ad atasan mereka akan memecatnya karena anaknya akan terganggu pekerjaannya jika bersekolah. 


\section{Eksploitasi seksual}

Pada scene ini terlihat orang tua yang sedang berunding dengan atasannya (As'ad dan bapaknya) yang membantu perekonomian mereka yang menyukai anak peremupannya, yang berencana untuk menikahkabannya padahal anaknya masih dibawah umur yang baru baligh masih berusia 11 tahun, dan kakanya Zain yang tidak menerima adiknya yang didandani seperti wanita penghibur oleh ibunya lantas menanyakan hal tersebut kepada ibunya, tetapi ibunya mencari alasan untuk menenangkan anaknya (Zain) yang hendak mengusir mereka. Bentuk penjualan orang tua ini atas anaknya ini termaksud kepada eksploitasi seksual karena menyerahkan anaknya yang masih dibawah umur yang mana belum waktunya untuk bisa dinikahkan, dan ini atas dasar ekonomi agar meringankan perekonomian keluarganya, sehingga mengkorbankan anaknya sendiri.

\section{Eksploitasi fisik dan Eksploitasi seksual}

Pada scene ini nampak saat anak perempuannya (Sahar) yang dipaksa oleh orang tuanya, saat Sahar hendak akan dibawa kabur oleh kakanya (Zain) untuk mengamankannya. Tetapi itu semua tidak berhasil, karena terdahului oleh ibunya yang sudah memaksa, menarik anaknya, padahal anaknya tidak mau, dan memohon-mohon untuk tidak dibawa. Bahkan saat kakanya (Zain) hendak menolongnya dengan membujuk ibunya, tetapi hanya pukulan dan cacian yang diterima, juga ancaman karna menghambat kehendak orang tuanya, ayahnya pun dengan sigap langsung menggendong paksa anaknya karna sudah bosan mendengar tangisannya setiap hari dan dianggap hanya menjadi beban keluarganya.

Tindakan ini termasuk kedalam bentuk eksploitasi fisik karena sudah menyiksa memukul anaknya yang sedang memohon untuk tidak dijerumuskan kedalam kejahatan (eksploitasi), serta ancaman dan bentakan yang didapat dari orang tuanya. Serta juga menjadi bentuk eskploitasi seksual karna anaknya telah dijerumuskan kedalam penjualan atau pengorbanan anak perempuannya yang masih dibawah umur dengan dinikahkan kepada bosnya.

\section{Eksploitasi ekonomi}

Jika pada scene ini menunjukan saat Rahil imigran illegal yang sedang meminta tolong kepada Aspro untuk dibuatkan kartu identitas dengan harga murah karena penghasilannya yang sedikit, dan Aspro meminta dibayar dengan anaknya sebagai jaminan. Dan Rahil akan mendapatkan kartu identitasnya gratis, tetapi tdak mungkin Rahil akan menyerahkan anaknya yang mana itu harta satusatunya yang paling berharga.

Disini menunjukkan bentuk eksploitasi ekonomi karena telah mengancam atas perkonomian yang rendah dan kondisi yang tidak layak atau resmi. Untuk mengambil anak orang dengan tujuan untuk diperdagangkan atau diperbudak.

6. Eksploitasi ekonomi dan ekploitasi sosial

Di scene ini menampakkan saat Zain yang sedang meminta tolong kepada Aspro yang sedang mencari Rahil yang sudah tidak pulang dalam waktu lama, karna Aspro yang dikenal dekat Rahil maka Zain menanyakan kepadanya, walaupun kenal tapi tidak tahu keberadaan Rahil sekarang. Dan lagi-lagi Aspro meminta kepada Zain untuk mengambil Yonas (anaknya Rahil). Itu pun tidak hanya sekali Aspro 
memintanya, tetapi beberapa kali, setiap Zain mendatanginya. Sampai akhirnya suatu hari Zain menyerah karena Rahil tak kunjung ditemukan dan sudah tidak kuat bertahan mencari makan untuk mengasuh anak Rahil untuk bertahan hidup selain itu Zain juga memiliki keinginan untuk pergi keluar negeri untuk mendapatkan hidup yang baru, dan karna Aspro dapat membantunya, maka Zain dengan berat hati menyerahkan Yonas (anak Rahil) kepada Aspro, untuk olehnya akan disalurkan ke perdagangan anak.

Perdagangan atau perbudakan anak ini termaksud kedalam bentuk eksploitasi ekonomi karena, penyerahan anak ini juga dikarenakan tekanan ekonomi dan juga untuk mendapat keuntungan tersendiri dari yang memanfaatkan anak yang terlantar untuk dijual ke para orang kaya. Selain itu termasuk bentuk eksploitasi sosial karena anak mendapat tekanan emosional karna beban hidup yang dialami.

7. Eksploitasi sosial dan eksploitasi fisik

Saat mulai puncak film pada scene ini konflik film mulai terlihat, yang mana saat Zain pulang ke rumah untuk meminta surat-surat atau kartu identitas ke orang tuanya untuk persyaratan dia bisa ke luar negeri, tetapi saat ayahnya marah, dia tidak sengaja menyebutkan surat dari rumah sakit. Dari situ Zain mulai curiga dengan siapa yang ada di rumah sakit. Yang awalnya ibunya menutupi untuk memberitahu kepada Zain. Tetapi karna Zain memaksa terus mendesak keluarga terutama ayahnya, akhirnya ayahnya dengan berat hati memberitahunya. Dan itu menjadikan Zain geram dan marah yang tidak membendung serta dendam terhadap Sa'ad yang memberanikan Zain melakukan hal gila untuk membunuh Sa'ad yang telah jahat dan tega melakukan ini kepada adik tersayangnya.

Tragedi ini masuk kedalam jenis kejahatan eksploitasi sosial karena telah mengganggu psikis anak akibat perbuatan jahat orang tuanya yang tidak bertangggung jawab. Sehingga anaknya berani melakukan perbuatan kriminal.

\section{Eksploitasi sosial}

Untuk scene terakhir ini, dimana Zain yang akhirnya ditangkap karna Tindakannya yang sudah diluar batas yang sudah berani hendak membunuh Sa'ad, yang membuatnya dimasukan ke penjara anak, tetapi saat di penjara Zain menonton acara siaran di TV yang menyuarakan tentang ketidakadilan terhadap anak dan menyalurkan suara mereka. Maka Zain langsung menghubungi nomor siaran tersebut dari telepon penjara. Disana dia mencurahakan seluruh keluh kesah atas segala konflik yang dialaminya. Dan pendapatnya atas orang dewasa yang belum bisa menjalankan tanggung jawabnya dan melakukan hal-hal yang semena-mena terhadap anak.

Dari sikap Zain yang diambil untuk menyuarakan suaranya atas semua yang dialaminya dapat dilihat bagaimana psikis anak itu terganggu karena penghambatan emosional anak. Sampai tidak sedikit kata kasar yang keluar karena emosi yang tidak stabil. Dari semua yang dialami Zain ini menggambarkan kejadian yang termaksud kedalam jenis bentuk eksploitasi sosial.

\section{Kesimpulan}

Penelitian ini meneliti unsur instristik, keterkaitan antar unsur dan bentuk-bentuk eksploiasi anak dalam naskah film Capharnaum karya Nadine Labaki. Lalu menganilisis 
menggunakan kajian Strukturalisme obyektif. Berdasarkan analisis strukturalisme obyektif dalam unsur instristik yang terdapat dalam film Capharnaum: tema tentang "kejahatan", plot/alur ceritanya maju-mundur (Campuran), Tokoh terdapat enam aktor, yang dikategorikan kedalam dua tokoh: tokoh utama; Zain, Sahar, Souad, Selim, dan Rahil, dan Aspro. Tokoh tambahan; Yonas, Nadine Al-Alam, Maysoun dan Harout. Untuk latar tempat diambil sutradara mengambil lokasi di pemukiman rumah susun yang kumuh di Lebanon, ruang Persidangan, pasar, taman hiburan dan penjara. Sedangkan latar waktu pada film Capharnaum terjadi di siang dan malam hari. Sudut pandang dalam film Capharnaum sudut pandang persona orang ketiga yaitu sudut pandang yang menjelaskan cerita dari sudut pandang (Dia) "Zain" tetapi pengarang, narrator bisa menceritakan apa saja yang berhubungan dengan tokoh "dia" tersebut. Amanat dari film ini adalah orang dewasa perlu mempunyai persiapan yang matang sebelum membangun keluarga dan mempunyai anak, agar dapat memenuhi hak-hak anak dan tanggungjawabnya. Juga bentuk-bentuk eksploitasi anak yang terdapat dalam film Capharnaum terdapat empat jenis Ekploitasi; yang terdapat dalam naskah film terdapat; 4 eksploitasi sosial, 2 eksploitasi ekonomi, 2 bentuk eksploitasi fisik, dan 2 eksploitasi seksual.

\section{Referensi}

Delaney, S. (2006). Melindungi Anak-Anak Dari Eksploitasi Seksual \& Kekerasan Seksual dalam Situasi Bencana dan Gawat Darurat. Medan: Restu Printing.

Haider, A. (2019). Retrieved from Capernaum: Film menyayat hati tentang anak-anak dan masa kecil. Bbc.Com. Retrieved from https://www.bbc.com/indonesia/vert-cul-47342168

Jamaludin, A. (2016). Dasar-Dasar Patologi Sosial. Bandung: Pustaka Setia.

Kridalaksana. (2005). Mongin-Ferdinand De Saussure (1857-1913). Jakarta: Yayasan Pustaka Obor Indonesia.

Sangidu. (2018). Strukturalisme dalam Bahasa Arab. Yogyakarta: Gadjah Mada university press.

Scholes, R. (1977). Structuralisme In Literature. New York: Yale University Press.

Wibowo, W. (2011). Cara Cerdas Menulis Artikel Ilmiah. Jakarta: kompas.

Yonata, F., \& Mujiyanto, Y. (2017). The Representation of Gender in English Textbooks in Indonesia. Language Circle: Journal of Language and Literature, 12(1), 91. https://doi.org/10.15294/lc.v12i1.11473 